\title{
Android Based Application of Bussines License at Department Of Industry and Trade In Jayapura City
}

Fegie Yoanti Wattimena', Lukas Batlyakru ${ }^{2}$

Faculty Of Science \& Technology ${ }^{1,2}$

University of Ottow Geissler,

Komp. pendidikan kristen, Kotaraja Dalam, Vim, Abepura, Kota Jayapura, Papua 99224, Indonesia ${ }^{1,2}$

e-mail: fegiywattimena.travel@gmail.com ${ }^{1}$, lbatlyakru@gmail.com ${ }^{2}$

To cite this document:

Wattimena, F. Y., \& Batlyakru, L. (2021). Android Based Application of Bussines License at Department Of Industry and Trade In Jayapura City. IAIC Transactions on Sustainable

Digital Innovation (ITSDI), 3(1), 66-75.

DOI: https://doi.org/10.34306/itsdi.v3i1.521

\begin{abstract}
Android Based Application of Bussines License at Department Of Industry and Trade In Jayapura City was built with the aim of making it easier for applicants to apply for SIUP online using cellphones and to improve public services at the Jayapura City Industry and Trade Office. The processing of a Trade Business Permit (SIUP) which has been done manually, which is submitted directly to the Jayapura City Office of Industry and Trade, can be done by accessing it via an Android phone. The research methods used are 1) Data collection methods are carried out through literature studies, interviews and documentation, 2) application development methods with communication stages, planning quickly, designing quickly, modeling and designing quickly, forming prototypes, software to users and feedback. Programming language used is PHP MYSQL and AppGeyser. The results of the design are in the form of an application that can process input data: applicant's personal data, company data, submission data, admin data, data confirmation, SIUP upload and the resulting output is SIUP data print, SIUP application number report.
\end{abstract}

Keywords: SIUP, Android, Prototype, Mobile

\section{Introduction}

Public services are part of national development to increase public participation as citizens. [1] In relation to this, the Jayapura City Industry and Trade Office organizes public services that aim to improve licensing regulations or regulate public behavior towards awareness of the importance of SIUP (Trade Business Permit). Especially in offices that have access to large data processing, because data processing is no longer possible using bookkeeping methods and is less effective and efficient. Licensing services at the Jayapura DISPERINDAG are still done manually, the procedure for obtaining a business license that has been common so far starts from visiting the information section to ask what information the applicant must fulfill to get a permit, then visiting the registration section to request and fill out a permit registration form. After filling out the registration form, submit an application for registration of a permit and requirements for approval in the determination section. After the registration section will process and validate the authenticity of the document, then the permit document will be submitted to the survey section to check whether the applicant's business location complies with the permit requirements or not. If the permit meets the requirements, 
the permit will be issued and ratified by the Head of the Jayapura City Office, but if it is not appropriate, the permit will be rejected by the determination section. The development of smartphone technology today has experienced many changes very rapidly, along with the increasing human needs and complex. Android smartphone which was originally only used by academics and the military, is now widely used in various fields, such as business, health, education, games and so on. This encourages experts to further develop Android smartphones in order to help human work or even exceed the ability of human work. [2]. This study aims to design and build an android-based business license application. This application is expected to replace the old licensing system, providing industry and trade information related to SIUP (Trade Business License) data. The applicant for the permit letter fills out the application form online, it can be done anywhere and anytime using an android phone. The application is expected to improve public services by the Jayapura City Industry and Trade Office which is maximum, fast, precise, cost-effective, and able to present statistics on the number of licensing data granted.

\section{Research Method}

\subsection{Framework of thinking}

The framework of thinking in this study describes the steps that will be carried out in the study as shown in Figure 1 below::

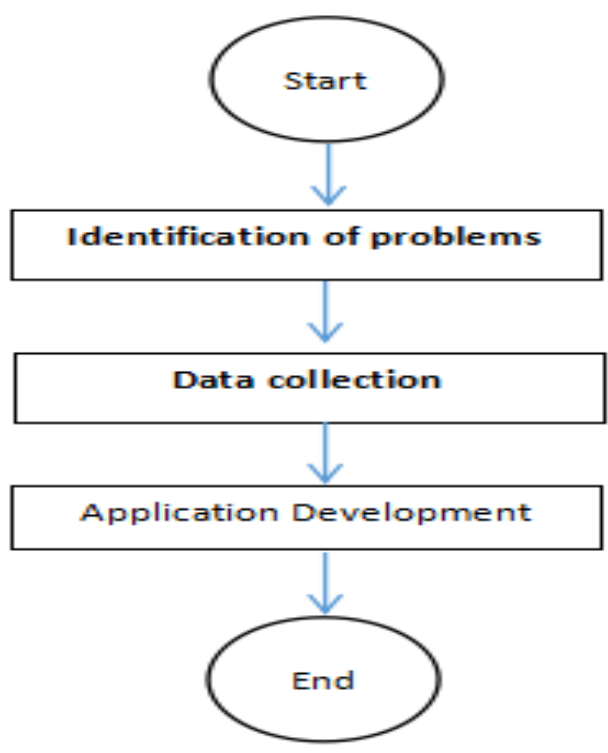

Figure 1. Framework of thinking

\subsection{Method of collecting data}

The data collection methods in this research are 1) Literature Study, conducting a review of similar research from journal articles and studying related theories that support problem solving for research. 2) Interviews, interviews were carried out directly with related parties for the Disperindag of Jayapura City, 3) Documentation, to obtain data related to filling out the SIUP form which is currently running and collecting data on the completeness of letters/documents for each applicant, examples of SIUP report forms etc. [3]

\subsection{System Development Method}


The system development method used is a prototype process model with stages of communication, planning quickly, designing quickly, modeling and designing quickly, forming prototypes, submitting software to users and giving feedback. [4]

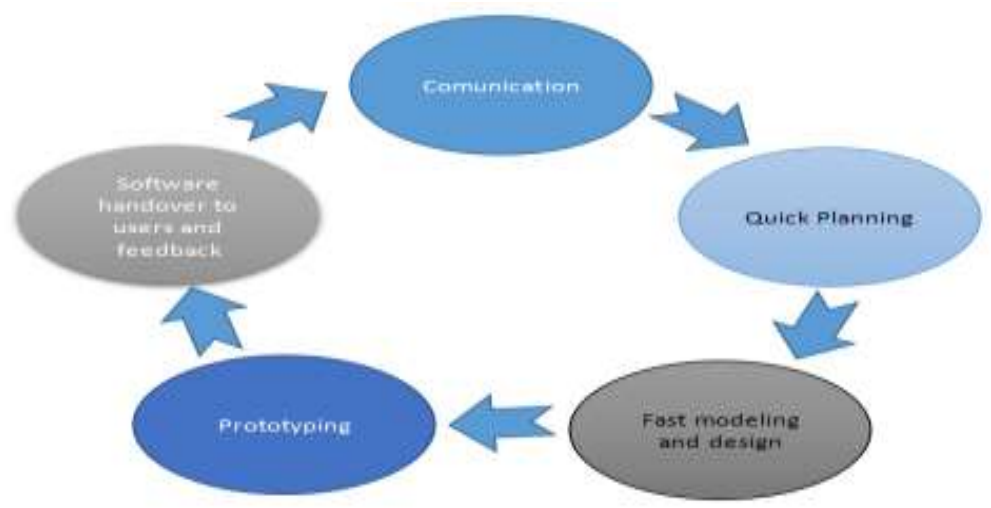

Figure 2. Model Proses Prototipe [4]

\subsection{Literature Review}

Research conducted by Anggi Andriyadi, Syela Angreani (2018), with the title "Sistem Informasi Perizinan Siup \& Situ Pada Kantor PTSA Kota Bandar Lampung Berbasis Web", explained that the Online Licensing Information System can facilitate applicants in the SIUP management process. The method used in this study is the waterfall method, the method of designing the DFD (Data Flow Diagram) model with the PHP (Hypertext Preprocessor) programming language and the database used MYSQL [5]

Subsequent research by Devy Dian Pratama (2018) entitled "Sistem Informasi Registrasi Pelayanan Perizinan Kabupaten Nganjuk", an information system that was built to meet the needs of obtaining a license (SIUP) for a Trading Business Permit. In this study, the author uses the DFD (Data Flow Diagram) model design method with the PHP (Hypertext Preprocessor) programming language and the MYSQL database used. [6]

Research by Wagino and Silvia Ratna with the title Aplikasi Surat Izin Usaha Perdagangan (SIUP) Pada Badan Penanaman Modal Dan Perizinan Terpadu Kota Banjarmasin, bertujuan untuk menghasilkan suatu sistem atau aplikasi untuk mempermudah kinerja proses perizinan pada Badan Penanaman Modal Dan Perizinan Terpadu Kota Banjarmasin. Perizinan SIUP (Surat Izin Usaha Perdagangan) secara komputerisasi dapat mempermudah dari pihak pemohon untuk mendaftarkan perusahaannya pada BPMPT (Badan Penanaman Modal Dan Perizinan Terpadu) dan juga dari pihak BPMPT untuk meminimalisir SDM (Sumber Daya Manusia) yang ada dan dalam pengarsipan data dapat lebih rapi dan lebih tahan lama. Sistem Ini dirancang dengan mengguankan Bahasa pemrograman borland delphi 7 dan menggunakan database Microsoft Acces. Diharapkan dengan adanya aplikasi ini pekerjaan penerbitan SIUP dan pengarsipan pada Badan Penanaman Modal Dan Perizinan Terpadu Kota Banjarmasin menjadi lebih mudah dan efektif. [7]

Based on research that has been done by Anggi Andriyadi, Syela Angreani (2018), Devy Dian Pratama (2018), Wagino, Silvia Ratna, Fathur Rahman (2019) as far as the author's search there is no research on SIUP made based on android/mobile and using development methods The prototype process model system, for the process of making SIUP at the Jayapura City Industry \& Trade Office, is still manual and there is no application for processing a Trading Business Permit developed by the Jayapura City Industry Office. 


\section{Findings}

Based on the problems that have been presented in the introduction, the problem formulation and problem boundaries can be described as follows :

\subsection{Problem}

The research problem is how to design and build Android Based Application of Bussines License at Department Of Industry and Trade In Jayapura City with the following problem limitations:

a. Android display design page: Home, Halaman visi misi, Tentang Kami

b. Data entry: Data diri pemohon, Data perusahaan, Data pengajuan, Data admin, Konfirmasi data , Upload SIUP

c. The resulting output: Cetak data SIUP, Laporan Jumlah pengajuan SIUP

d. The application is built using the PHP programming language and the database uses Mysql [8] [9] [10] dan AppGeyser.[11]

\subsection{Research Implementation}

Based on the results of application development using the Prototype process model and using the PHP MYSQL programming language and AppGyeser, the implementation results are presented in the following figure:

a. Display page Beranda Admin

Figure 3 is a view of the admin home page, where the admin can see every data inputted into the system.

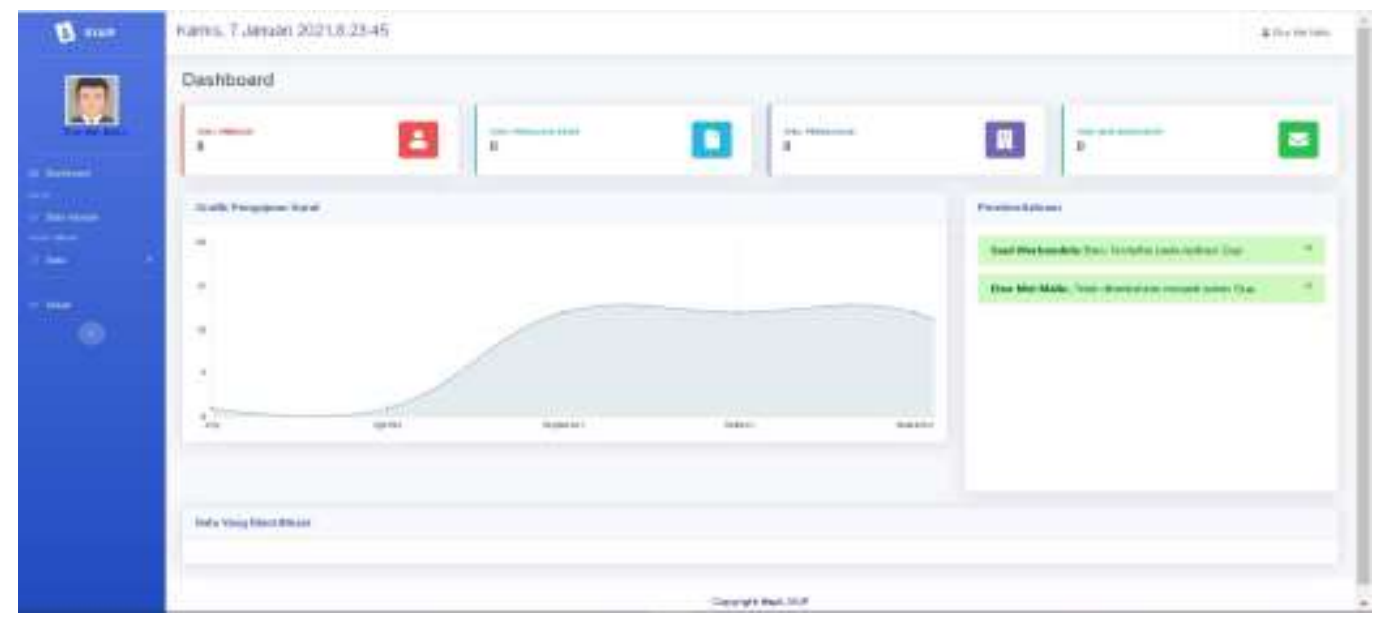

Figure 3. Display page Beranda Admin

\section{b. Display page Utama}

Figure 4 is the main page of the application, where users can access the home page, vision and mission, about us, siup service, registration and login. 


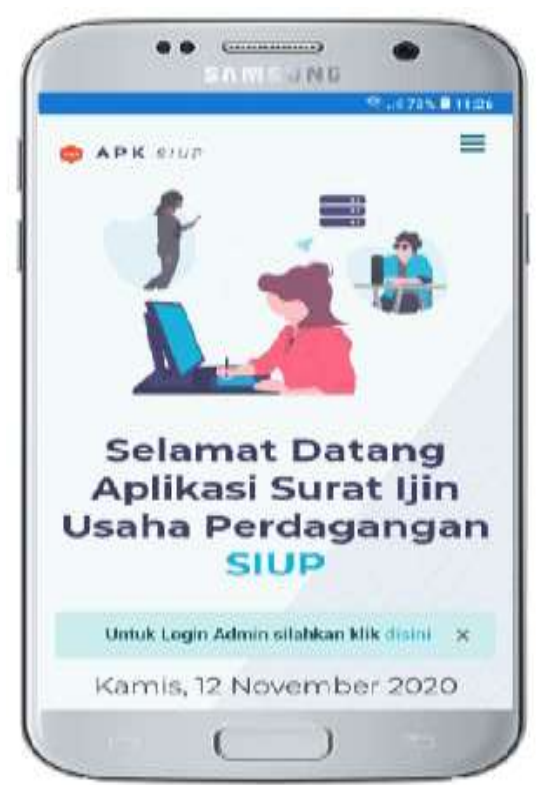

Figure 4. Display Halaman Utama

c. Display page Daftar Akun

On this page view, the applicant is required to register an account by filling in the full name, username, password, email, no_hp, photo in order to get an account to access.

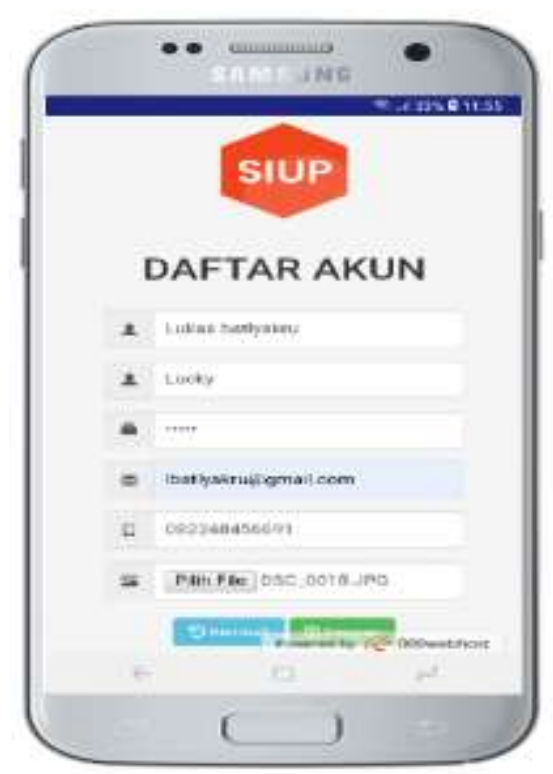

d. Display page Verifikasi Email

Figure 5. Display page Daftar Akun

Figure 6. applicants get notification to email for verification. 


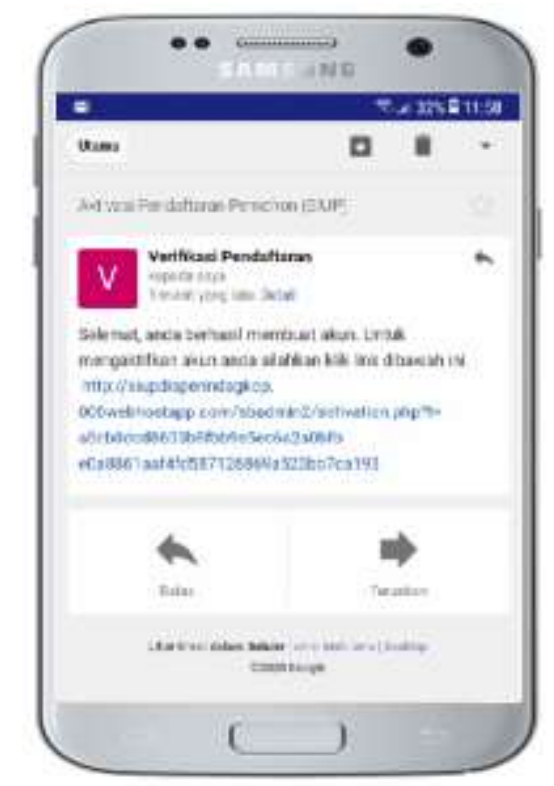

Figure 6. Display Page Verifikasi Email

e. Display page Login

Figure 7. The applicant logs in by filling in the username/email and password to be able to access the SIUP service menu.

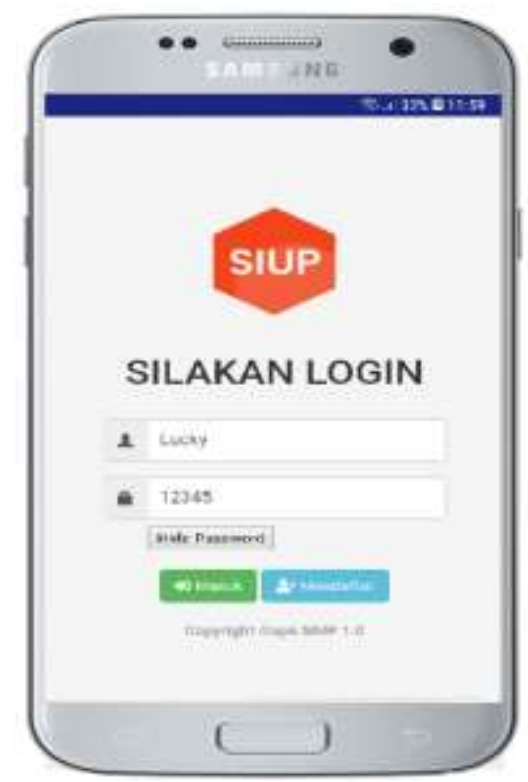

Figure 7. Display page Login

f. Display page Utama Pemohon

Figure 8. Applicants can see the applicant input form, company form, submission form and input data from each input form 


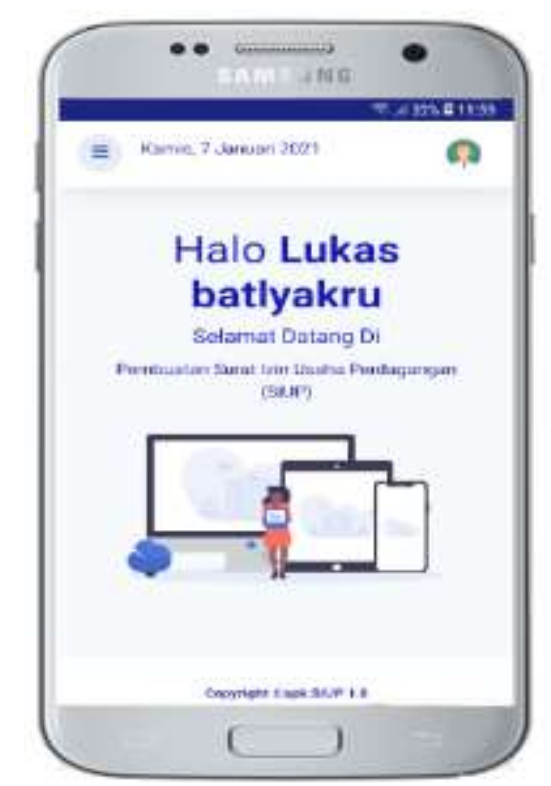

Figure 8. Display page Utama Pemohon

g. Display Page Entry Data Diri Pemohon

Figure 9. the applicant enters the applicant's personal data on the applicant form

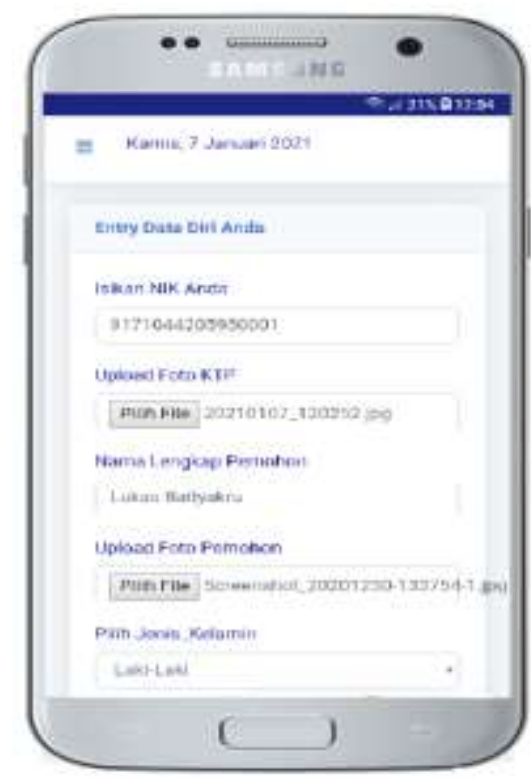

Figure 9. Display page Entry Data Diri Pemohon

h. Display page Entry Data Perusahaan

Figure 10. the applicant inputs company data on the company form 


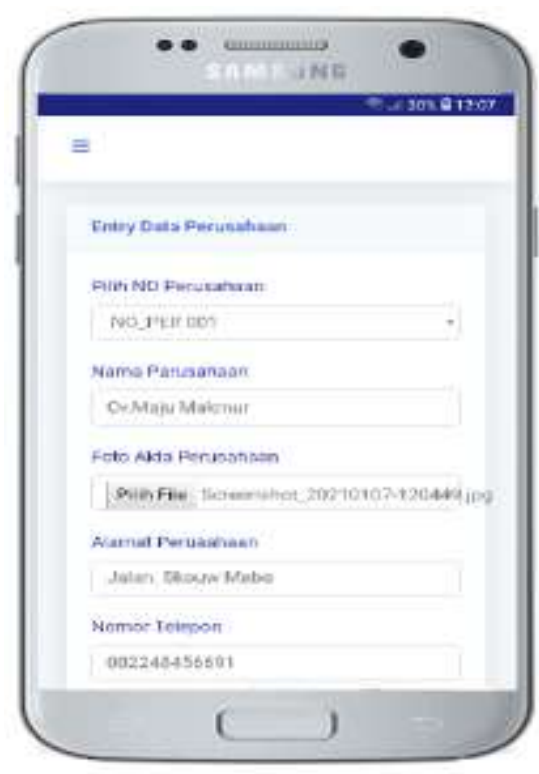

Figure 10. Display page Entry Data Perusahaan

i. Display page Entry Pengajuan Surat

Figure 11. the applicant inputs the submission data on the application form.

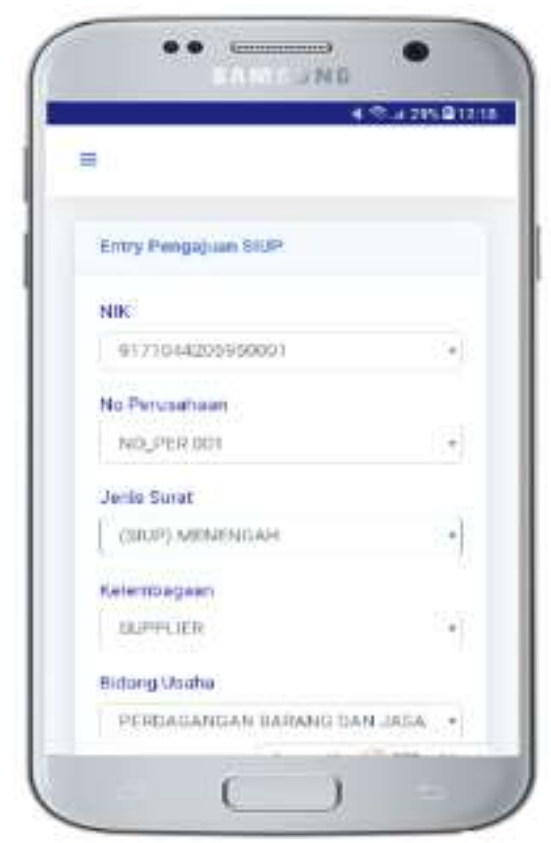

Figure 11. Display page Entry Pengajuan Surat

j. Display Surat ljin Usaha Perdagangan (SIUP)

Figure 12. The applicant can view the SIUP that has met the requirements and has been ratified by the competent authority in the form of an electronic document 


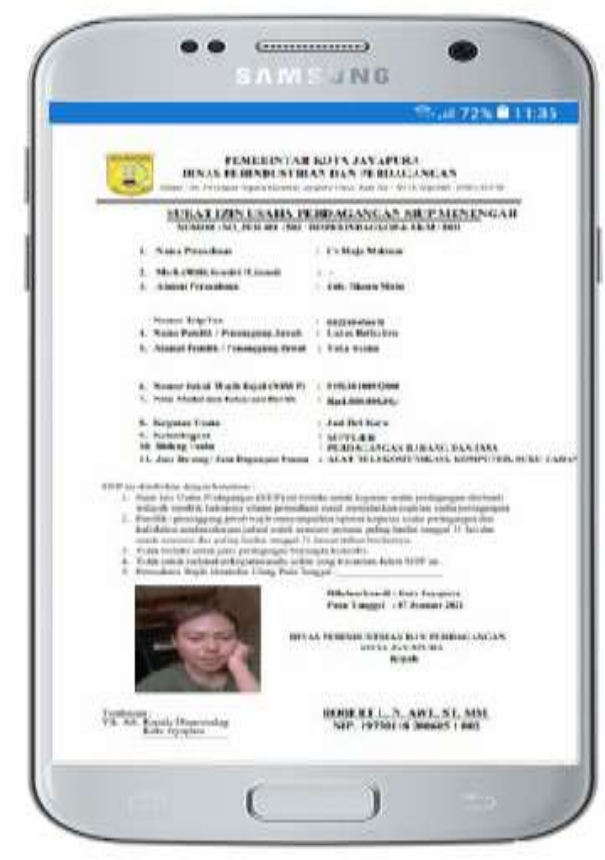

Figure 12. Display Surat ljin Usaha Perdagangan (SIUP)

\section{Conclusion}

Android Based Application of Bussines License at Department Of Industry and Trade In Jayapura City has been successfully built using the Prototype process model development method and the PHP MYSQL and AppGyeser programming languages with the outputs of 1) electronic SIUP which has been signed by the authorized official, 2) Statistical report on the amount of data submitted.

\section{References}

[1] H. Soetarto, A. M. Harto, and A. Syaiful, "Pengelolaan Pelayanan Surat Ijin Usaha Perdagangan (Siup) Pada Usaha Kecil Oleh Dinas Penanaman Modal Dan Pelayanan Terpadu Satu Pintu Kabupaten Sumenep," Public Corner, vol. 14, pp. 56-78, 2019, doi: https://doi.org/10.24929/fisip.v14i3.706.

[2] F. Y. Wattimena, R. Koibur, D. R. A. Mamisala, and S. Andryana, "Experd System Of Obesity Diagnosis Using Backward Chaining Method And Certain Factor," IAIC Trans. Sustain. Digit. Innov., vol. 1, no. 2 April, pp. 116-128, 2020, doi: 10.34306/itsdi.v1i2.106.

[3] Z. A. Hasibuan, Metodologi Penelitian Pada Bidang IImu Komputer Dan Teknologi Informasi. 2007.

[4] L. Setiyani, Rekayasa Perangkat Lunak [Software Engineering], no. May. 2019.

[5] A. Andriyadi and S. Angreani, "Sistem Informasi Perizinan Siup \& Situ Pada Kantor PTSA Kota Bandar Lampung Berbasis Web," J. Sist. Inf. Manaj. Basis Data, vol. 01, no. 02, pp. 116-127, 2018.

[6] D. D. Pratama, "Sistem Informasi Registrasi Pelayanan Perizinan Kabupaten Nganjuk," J. 
Simki-Techsa, 2018, [Online]. Available: http://simki.unpkediri.ac.id/mahasiswa/file_artikel/2018/14.1.03.03.0002.pdf.

[7] W. Wagino, S. Ratna, and F. Rahman, "Aplikasi Surat Izin Usaha Perdagangan (SIUP) Pada Badan Penanaman Modal Dan Perizinan Terpadu Kota Banjarmasin," Technol. J. IIm., vol. 10, no. 3, pp. 147-155, 2019, doi: 10.31602/tji.v10i3.2260.

[8] F. Y. Wattimena, S. Tamalonggehe, and M. Sedubun, "Sistem Informasi Ruang Baca Fakultas Sains \& Teknologi Universitas Ottow Geissler Papua," J. IIm. Teknol. Inf. dan Robot., vol. 1, no. 2, pp. 22-26, 2019, doi: 10.33005/jifti.v1i2.19.

[9] F. M. Kromann, Beginning PHP \& My SQL from novice to professional, Fifth. Aliso Viejo, CA USA, 2018.

[10] W. Yudha, Yudhanto., \& Ardhi, Mudah Membuat dan Berbisnis Aplikasi Android dengan Android Studio. Jakarta: PT. Elex Media Komputindo, 2017.

[11] H. Isyaf, Aplikasi Android dalam 5 menit. Jakarta: PT Elex MediaKomputindo, 2016. 